\title{
Role of $5-\mathrm{HT}_{1 \mathrm{~A}}$ receptors in antidepressant-like effect of dichloromethane fraction of Kielmeyera coriacea in rats subjected to the forced swim test
}

\author{
F.J . Otobone, V.R. Sela, S. Obici, L.Y. Moreira, D.A.G. Cortez, E.A. Audi
}

Department of Pharmacy and Pharmacology, U niversity of Maringá, PR, Brazil

Received: 20.9.2006

Revised: 9.4.2007

Accepted: 11.4 .2007

Correspondence to:

E. A. Audi

E-mail: eaaudi@uem.br

\begin{abstract}
O bjective: We examined the involvement of 5-HT neurotransmission on the antidepressantlike effect of the dichloromethane (DcM) fraction of an extract from Kielmeyera coriacea stems.

Materials and M ethods: Male Wistar rats treated chronically (45 days, gavage) with the DCM fraction received an intradorsal raphe nucleus (DRN) microinjection of saline or $5-\mathrm{HT}_{1 \mathrm{~A}}$ receptor ligands and were evaluated in the forced swimming test (FST) and in the open-field test (OFT).

Results: The D cM fraction $(5.0 \mathrm{mg} / \mathrm{kg}$ ) reduced immobility time in the FST without altering locomotion in the OFT. IntraD RN microinjection of the 5- $\mathrm{HT}_{1 \mathrm{~A}}$ receptor agonist, (+)-8$\mathrm{OH}$-DPAT $(0.10 ; 0.20$ or $0.33 \mu \mathrm{g})$ increased immobility time and reduced locomotion at the higher dose whereas the $5-\mathrm{HT} 1 \mathrm{~A}$ antagonists, (-)-pindolol $(0.10 ; 0.20$ or $0.40 \mu \mathrm{g})$ or WAY $100635(0.11 ; 0.22$ or $0.43 \mu \mathrm{g})$ did not produce any effect in the behavioral tests. IntraDRN $(+)-8-0 \mathrm{H}-\mathrm{DPAT}(0.20$ or $0.33 \mu \mathrm{g})$ in rats treated with the DcM fraction $(5.0$ $\mathrm{mg} / \mathrm{kg}$ ) blocked the changes in the immobility time or in locomotion produced by each drug. Intra-DRN (-)-pindolol $(0.10 \mu \mathrm{g})$ or WAY100635 $(0.43 \mu \mathrm{g})$ in rats treated with a subactive dose of the DCM fraction $(4.0 \mathrm{mg} / \mathrm{kg})$ synergistically reduced immobility time in the FST.

Conclusion: The DCM fraction of Kielmeyera coriacea produced an antidepressant-like effect in the FST and interacted with $5-\mathrm{HT}_{1 \mathrm{~A}}$ receptor ligands. Activation of $5-\mathrm{HT}_{1 \mathrm{~A}}$ receptors into DRN by (+) 8-O H-D PAT produced detectable changes in the FST or in the OFT.
\end{abstract}

KEY WORDS: Depression, dorsal raphe nucleus, Kielmeyera coriacea, 5- $\mathrm{HT}_{1 \mathrm{~A}}$ receptor
Kielmeyera coriacea Mart. (Clusiacea) is a Brazilian plant commonly known as pau santo. A decoction of the stems is used to treat several tropical diseases including schistosomasis, leishmaniasis, malaria and fungal and bacterial infections. ${ }^{11]}$ High performance liquid chromatography (HPLC) analysis of the hydroethanolic extract (HE) and the dichloromethane (DcM) semipurified fraction of K. coriacea stems detected the presence of xanthones, triterpenes and their biphenyl derivatives. ${ }^{[2,3]}$ Previous studies conducted in our laboratory showed that chronic administration of the HE and the DcM semipurified fraction of $\mathrm{K}$. coriacea stems by gavage reduced the immobility time in rats subjected to the forced swimming test (FST) suggesting an antidepressant-like effect. ${ }^{[3,4]}$

Drugs acting on the serotonin (5-HT, 5-hydroxytryptamine) system have been shown to be effective in the treatment of depressive disorders. ${ }^{[5]}$ Somatodendritic $5-\mathrm{HT}_{1 \mathrm{~A}}$ autoreceptors located in the dorsal raphe nucleus (DRN) in the midbrain, play a particularly important role in this antidepressant activity. These receptors are considered to be the principal inhibitory regulators of 5-HT neuronal activity, playing an important role in the physiological control of the ascending 5-HT pathway. Stimulation of these 5- $\mathrm{HT}_{1 \mathrm{~A}}$ receptors in the DRN reduces the firing of 5-HT neurons and produces an anti-5-HT effect through the reduction in 5-HT release. ${ }^{[6-8]}$

A delay of usually 2-4 weeks in the onset of antidepressant activity ${ }^{\mid 5,6]}$ is attributed to activation of the inhibitory somatodendritic 5- $\mathrm{HT}_{1 \mathrm{~A}}$ autoreceptors located in the DRN. This DRN somatodendritic 5- $\mathrm{HT}_{1 \mathrm{~A}}$ autoreceptor-mediated inhibition of antidepressant activity can be induced by exogenously applied 5-HT, 5-HT 1 agonists or by acute administration of 5HT re-uptake inhibitors. All these factors inhibit neuronal firing and consequently, decrease 5-HT release in different areas of 
the forebrain; and may hinder the therapeutic efficacy of an antidepressant. After continued stimulation, these feedback mechanisms become desensitized and the enhanced 5-HT availability is able to enhance 5-HT neurotransmission. ${ }^{[8]}$

Current strategies aim to improve the efficacy of antidepressant drugs including the co-administration of $5-\mathrm{HT}_{1 \mathrm{~A}}$ and / or $5-\mathrm{HT}_{1 \mathrm{~A} / 1 \mathrm{~B}}$ autoreceptor antagonists. These 5 -HT antagonists can facilitate the antiimmobility effect of subeffective doses of antidepressant drugs in rats and mice in the FST ${ }^{[9]}$ and thus, accelerate the effects of these drugs in patients with major depression. ${ }^{[10]}$

The FST is one of the most frequently used screening tests for antidepressant drugs in rodents. It shows great sensitivity to different antidepressant classes and permits determination of the neurobiological mechanisms underlying stress and antidepressant responses. Different classes of antidepressant drugs are effective in decreasing immobility time in the FST. ${ }^{[11]}$

In this study, we examined the involvement of 5-HT neurotransmission, particularly that mediated by somatodendritic $5-\mathrm{HT}_{1 \mathrm{~A}}$ autoreceptors in the antidepressant-like effect of the DcM semipurified fraction of a K. coriacea stem extract. We assessed the effects of chronic administration of the test substance (DcM fraction) alone or in combination with intraDRN microinjections of $5-\mathrm{HT} 1 \mathrm{~A} / 1 \mathrm{~B}$ agonists or antagonists in rats subjected to the FST or open field test (OFT). An effective dose of the DcM fraction was given along with an intraDRN microinjection of the $5 \mathrm{HT}_{1 \mathrm{~A}}$ agonist, (+) 8-hydroxy-2-di-n-propylamino-tetralin (8-OH-DPAT) while a subactive dose of the DcM fraction was given in combination with either the selective $5-\mathrm{HT}_{1 \mathrm{~A}}$ antagonist, $\mathrm{WAY}_{100635}$ or the $5 \mathrm{HT}_{1 \mathrm{~A} / 1 \mathrm{~B} /} \mathrm{B}$ adrenergic antagonist, (-)-pindolol.

\section{Materials and Methods}

\section{Animals}

Male Wistar rats, each weighing 180-200 g (Central Biotério, University of Maringá-UEM) were used. The rats were housed in groups of four per cage and maintained on a $12 \mathrm{~h}$ light/dark cycle (lights on at 7:00 h) under controlled temperature $\left(22 \pm 1^{\circ} \mathrm{C}\right)$, with freely available food and water. All experiments were carried out between 8:00 and 12:00 $\mathrm{h}$. The experimental procedures adopted were approved by the UEM Ethics Committee (\# 084-02/COBEA) and followed the norms recommended as international guiding principles for Biomedical Research Involving Animals (CIMS), Geneva, 1985.

\section{Plant material, extract and DcM semipurified fraction}

K. coriacea was collected near Mogi-Guaçu, São Paulo, Brazil in July 1999. A voucher specimen (\# SP 298-463) was deposited with the Herbarium of the State Botanical Institute, São Paulo, Brazil. The species was identified by Dr. Maria Claudia Young of the same institution. Dried and crushed stems $(1.0 \mathrm{~kg})$ of K. coriacea were exhaustively extracted by maceration with 38 $\mathrm{L}$ of ethanol/water $(9: 1)$ at room temperature for seven days, yielding $167.3 \mathrm{~g}$ of extract after evaporation of the solvents and lyophilization. After lyophilization, the crude HE extract from K. coriacea stems $(167.3 \mathrm{~g})$ was stored in a freezer at $-15^{\circ} \mathrm{C}$. In order to assess the stability of the DcM fraction, comparative chromatographic analyses were conducted before chronic treatment of the animals. The HE extract $(110.6 \mathrm{~g})$ was submitted to vacuum column chromatography (208.3 g silica gel) and eluted with hexane (1000 mL), dichloromethane (1000 $\mathrm{mL})$, ethyl acetate $(1000 \mathrm{~mL})$, acetone $(1000 \mathrm{~mL})$ and methanol/ water (1000 mL), yielding five fractions (F1: $1.8 \mathrm{~g}),(\mathrm{F} 2: 28.6 \mathrm{~g})$, (F3: $21.6 \mathrm{~g})$, (F4: $11.1 \mathrm{~g}$ ) and (F5: $29.5 \mathrm{~g}$ ) respectively. [Patent application \# 001342 with the National Patents Institute (INPI) on October 9, 2002].

\section{Stereotaxic operations}

Rats anaesthetized with sodium thiopental (Thiopentax ${ }^{\circledR}, 45$ $\mathrm{mg} / \mathrm{kg}$ i.p, Cristália) and local anesthetic agents ( $2 \%$ xylocaine + adrenaline) were positioned in the stereotaxic frame and cannulated using a guide cannula stereotaxically placed at the DRN. The stereotaxic coordinates were: $\mathrm{AP}=-7.1 \mathrm{~mm}, \mathrm{~L}=4.0$ $\mathrm{mm}, \mathrm{DV}=5.3 \mathrm{~mm}$, from the Paxinos and Watson atlas ${ }^{121}$ with reference to bregma for the tip of the $15 \mathrm{~mm}$-long stainless-steel cannula ( $0.6 \mathrm{~mm}$ external diameter) positioned $0.2 \mathrm{~mm}$ above the DRN. The cannula was inserted into the DRN at an angle of $34^{\circ}$ to the horizontal plane to avoid penetration of the midline sinus and the brain aqueducts. The stainless-steel guide cannulas were fixed to the skull with stainless-steel screws and self-polymerising acrylate resin and were closed with a stainless-steel wire to prevent obstruction. The animals were allowed to recover for five or six days before the experiments.

\section{Microinjections}

The rats were given microinjections while they were awake. A 17-mm needle $(0.3 \mathrm{~mm}$ outer diameter) was inserted into the guide cannula so that it extended $0.2 \mathrm{~mm}$ beyond the cannula tip. The microinjection needle was connected to a $10 \mu \mathrm{L}$ microsyringe (Hamilton 71-RN, USA) through a filled polyethylene tube (PE 10). The polyethylene tube was filled either with the drugs or with the control substance by aspiration. Solutions were injected with a microinfusion pump (Insight Equipments, Brazil) at a flow rate of $0.2 \mu \mathrm{l} / 30 \mathrm{~s}$. After each infusion, the needle was left in place for $30 \mathrm{~s}$ before being removed to allow the drug to be absorbed.

\section{Treatments}

The DcM fraction from K. coriacea stems was dissolved in a vehicle (water $+5 \%$ dimethylsulfoxide, DMSO). Solutions of (+)-8-OH-DPAT hydrobromide (Sigma-RBI), (-)-pindolol (Sigma$\mathrm{RBI}$ ) and $\mathrm{WAY}_{100635}$ (Sigma-RBI) were all dissolved in saline. To investigate the effects of $5-\mathrm{HT}_{1 \mathrm{~A}}$ autoreceptors located intraDRN on immobility time in FST or on the number of crossings in the OFT, rats were chronically treated by gavage (45 days) with the vehicle or DcM or received an intraDRN microinjection of the 5$\mathrm{HT}_{1 \mathrm{~A}}$ ligands ( $\mathrm{WAY}_{100635}$, (-)-pindolol or (+)-8-OH-DPAT) or saline. The doses of the DcM were based on previous studies conduced in our laboratory ${ }^{[3]}(+)$ 8-OH-DPAT, WAY $_{100635}$ and (-) pindolol doses used in our study were based in another studies. ${ }^{[13-16]}$

Forced swimming test (FST) and open field test (OFT)

Rats were individually forced to swim in an open cylindrical container (diameter $30 \mathrm{~cm}$, height $60 \mathrm{~cm}$ ), containing water of $45 \mathrm{~cm}$ depth at $25 \pm 1^{\circ} \mathrm{C}$. The test employed is essentially similar to that described by Porsolt et al. ${ }^{[11]}$ except for the water level. The water level has been increased $(45 \mathrm{~cm})$ in order to increase the sensitivity of the test. The rats lack a sense of the water's depth and their tails do not touch the bottom of the cylinder. This procedural modification is consistent with the practice of other authors ${ }^{[17]}$ and should be considered the present standard method. Animals were exposed to a pretest 
for $15 \mathrm{~min}, 24 \mathrm{~h}$ prior to the $5 \mathrm{~min}$ swim test. Each animal was considered immobile when it ceased to struggle and swim and remained floating in the water, only moving to keep its head above water. After the test, the animals were removed from the water, dried by the experimenter and placed in cages.

After $24 \mathrm{~h}$, the same animals were individually placed in the OFT $(40 \times 40 \times 40 \mathrm{~cm}$ ) square field, which was divided into 25 identical squares. The rats were observed to evaluate locomotor activity measured by the total number of crossings in the squares. After $30 \mathrm{~s}$ of habituation, the $5 \mathrm{~min}$ swim session in the FST or the 5 min locomotion session in the OFT was videotaped for subsequent measurement of the time of immobility or the number of crossings (all four feet being moved from one square to be placed in another constituted one crossing) by a trained observer. Two fluorescent lights provided diffuse overhead illumination (200 lux at the level of the arena).

\section{Histology}

Histological verification of the injection sites was carried out at the end of the behavioral experiments. The animals were anaesthetized by the intraperitoneal route (i.p.) with sodium thiopental and their brains were perfused through the heart with saline followed by $10 \%$ formaldehyde solution before being removed for histological analysis. After fixation, the brains were sectioned into $50 \mu \mathrm{m}$-thick slices in the coronal plane on a freezing microtome. The sites of the injections in the DRN were determined by comparing the sections with the Paxinos and Watson atlas. ${ }^{[12]}$ If the injection site was located outside the DRN (20.0\%), the animal was discarded.

\section{Data analysis}

Results are expressed as the mean \pm SE for each group. One-way or two-way analysis of variance (ANOVA) followed by an unequal Tukey's test for multiple comparisons, were used for the dose-effect or associated-treatments studies, respectively. Effects were considered statistically significant at $P \leq 0.05$.

\section{Results}

Table 1 shows the effects of intraNDR microinjections of saline, (+) 8-OH-DPAT $(0.10 ; 0.20$ or $0.33 \mu \mathrm{g}),(-)$-pindolol $(0.10,0.20$ or $0.40 \mu \mathrm{g})$ or $\mathrm{WAY}_{100635}(0.11 ; 0.22$ or $0.43 \mu \mathrm{g})$ on immobility time (s) in the FST and the crossings number in the OFT in rats chronically treated with vehicle (water $+5 \%$ DMSO). The 5-HT ${ }_{1 \mathrm{~A}}$ agonist, (+) 8-OHDPAT $(0.33 \mu \mathrm{g})$ significantly $(P<0.05)$ increased immobility time in the FST. and signficantly decreased $(P<0.05)$ the number of crossings in the OFT $\left(\mathrm{F}_{(3.34)}=4.7 ; \mathrm{P}=0.007\right)$. However, different doses of the 5 - $\mathrm{HT}_{1 \mathrm{~A}}$ antagonists, (-)-pindolol and $\mathrm{WAY}_{100635}$ did not affect the immobility time in the FST $\left(\mathrm{F}_{(3.38)}=1.7, \mathrm{P}=0.18\right)$ or $\left(\mathrm{F}_{(3.28)}=\right.$ $0.6, \mathrm{P}=0.59)$ or the number of crossings in the OFT $\left(\mathrm{F}_{(3.38)}=0.9\right.$, $\mathrm{P}=0.42)$ or $\left(\mathrm{F}_{(3.28)}=0.5, \mathrm{P}=0.67\right)$ respectively.

Table 2 shows the results of the treatment with saline or (+)-8-OH-DPAT $(0.20$ or $0.33 \mu \mathrm{g})$ in rats chronically treated with vehicle or the DcM fraction $(5.0 \mathrm{mg} / \mathrm{kg})$ in the FST. The two-way ANOVA showed an effect of (+)-8-OH-DPAT treatment $\left(\mathrm{F}_{(2.52)}=\right.$ 25.0, $\mathrm{P}=0.00001)$, of DcM treatment $\left(\mathrm{F}_{(1.52)}=6.5, \mathrm{P}=0.01\right)$ and of $(+)-8$-OH-DPAT X DcM interaction $\left(\mathrm{F}_{(2.52)}=6.76, \mathrm{P}=0.002\right)$ on immobility time. Post hoc Tukey's test detected that immobility time was significantly decreased by the DcM $(5.0 \mathrm{mg} / \mathrm{kg})$ and increased by $(+)-8-0 H-D P A T ~(0.33 \mu \mathrm{g})$ compared with the control

\section{Table 1}

Effects of 5- $\mathrm{HT}_{1 \mathrm{~A}}$ ligands on immobility time (s) in the forced swimming test and crossings number in the open field test

\begin{tabular}{ccc}
\hline Treatment $(\mu \mathrm{g})$ & $\begin{array}{c}\text { Immobility time }(\mathrm{s}) \\
\text { in forced swimming test }\end{array}$ & $\begin{array}{c}\text { Crossings number } \\
\text { in open field test }\end{array}$ \\
\hline $\begin{array}{l}\text { Control } \\
(+)-8-O H-D P A T\end{array}$ & $206.3 \pm 7.5$ & $118.1 \pm 13.4$ \\
0.10 & $233.7 \pm 16.8$ & $103.0 \pm 13.7$ \\
0.20 & $221.7 \pm 9.2$ & $124.6 \pm 12.9$ \\
0.33 & $251.4 \pm 10.6^{*}$ & $72.8 \pm 10.7^{*}$ \\
$(-)-$-pindolol & & \\
0.10 & $200.6 \pm 11.6$ & $109.3 \pm 12.4$ \\
0.20 & $218.3 \pm 8.6$ & $100.4 \pm 8.1$ \\
0.40 & $202.1 \pm 14.7$ & $125.5 \pm 4.8$ \\
WAY & & \\
0.11 & $220.4 \pm 5.9$ & $96.3 \pm 15.6$ \\
0.22 & $205.1 \pm 14.3$ & $102.1 \pm 15.7$ \\
0.43 & $204.9 \pm 11.1$ & $96.4 \pm 13.8$ \\
\hline
\end{tabular}

Data are means $\pm \mathrm{SE},(\mathrm{n}=9-15)$ of intra-DRN $(0.20 \mu \mathrm{L} / 30 \mathrm{~s})$ saline or $5-\mathrm{HT}$ ligands in rats chronically treated with vehicle (water $+5 \%$ DMSO). ${ }^{*} P<0.05$ compared to control groups

\section{Table 2}

Effects of DcM and intra-DRN (+)-8-OH-DPAT on immobility time(s) in the FST

\begin{tabular}{|c|c|c|}
\hline \multirow{2}{*}{ 5-HT $T_{1 A}$ agonist } & \multicolumn{2}{|c|}{$D c M(m g / k g)$} \\
\hline & $0 \mathrm{mg} / \mathrm{kg}$ & $5.0 \mathrm{mg} / \mathrm{kg}$ \\
\hline \multicolumn{3}{|c|}{$(+)-8-\bar{O}$-DPAT $(\mu \mathrm{g})$} \\
\hline 0 & $206.3 \pm 7.5$ & $145.4 \pm 10.9^{*}$ \\
\hline 0.20 & $221.7 \pm 9.2$ & $234.7 \pm 9.5$ \\
\hline 0.33 & $251.4 \pm 10.6^{*}$ & $238.5 \pm 8.6$ \\
\hline
\end{tabular}

Data are means \pm SE, $(n=8-12)$ after intra-DRN saline or $(+)$ 8-OH-DPAT $(0.20$ or $0.33 \mu \mathrm{g})$ in rats treated with vehicle or DcM $(5.0 \mathrm{mg} / \mathrm{kg})$. ${ }^{*} P<0.05$ compared to the control group

group. The addition of each dose of (+)-8-OH-DPAT reversed the antiimmobility effect produced by the DcM.

Table 3 shows the results of the treatment with saline, (-)-pindolol $(0.10 \mu \mathrm{g})$ or $\mathrm{WAY}_{100635}(0.43 \mu \mathrm{g})$ in rats chronically treated with vehicle or a subactive dose of DcM $(4.0 \mathrm{mg} / \mathrm{kg})$ in the FST. The two-way ANOVA showed an effect of (-)-pindolol treatment $\left(\mathrm{F}_{(1.30)}=8.6, \mathrm{P}=0.006\right)$ as well as a significant $(-)-$ pindolol $(0.10 \mu \mathrm{g}) X$ DcM $(4.0 \mathrm{mg} / \mathrm{kg})$ interaction, $\left(\mathrm{F}_{(1.30)}=6.3\right.$, $P=0.01)$, but not of DcM treatment $\left(F_{(1.30)}=0.4, P=0.53\right)$ on immobility time. In post hoc comparisons, Tukey's test detected a significant reduction in immobility time produced by the combination of (-)-pindolol and a subactive dose of DcM when compared to just the subactive dose of DcM $(P<0.05)$. The two way ANOVA detected a main effect of $\mathrm{WAY}_{100635}$ treatment $(\mathrm{F}(1,30)=14.6, \mathrm{P}=0.0006)$, the subactive dose of $\mathrm{DcM}(4.0$ $\mathrm{mg} / \mathrm{kg}),(\mathrm{F}(1,30)=16.1, \mathrm{P}=0.0004)$ and of the combination of $\mathrm{WAY}_{100635}$ and $\operatorname{DcM}(\mathrm{F}(1,30)=13,8, \mathrm{P}=0.0008)$ on immobility time in the FST on rats treated with a subactive dose of DcM $(4.0 \mathrm{mg} / \mathrm{kg})$. Post hoc Tukey`s comparisons showed a significant antiimmobility effect in rats exposed to the combination of 


\section{Table 3}

Effects of of a subactive dose of DcM in combination with intraDRN (-)-pindolol or WAY100635 on immobility time(s) in the FST

\begin{tabular}{|c|c|c|}
\hline \multirow[t]{2}{*}{$5-H T_{1 A}$ antagonist } & \multicolumn{2}{|c|}{$D c M(m g / k g)$} \\
\hline & 0 mg/kg (control) & $4.0 \mathrm{mg} / \mathrm{kg}$ \\
\hline - & $206.3 \pm 7.5$ & $202.6 \pm 13.8$ \\
\hline WAY $_{100635}(0.43 \mu \mathrm{g})$ & $204.9 \pm 11.1$ & $106.5 \pm 11.0^{*}$ \\
\hline (-)-Pindolol $(0.10 \mu \mathrm{g})$ & $200.6 \pm 11.6$ & $158.5 \pm 12.9^{\#}$ \\
\hline
\end{tabular}

Data are means \pm SE, $(n=8-10)$ after intraDRN saline, $(-)$-pindolol $(0.10 \mu \mathrm{g})$ or WAY100635 $(0.43 \mu \mathrm{g})$ in rats treated with vehicle or subactive dose of DcM $(4.0$ $\mathrm{mg} / \mathrm{kg}$ ). ${ }^{*} P<0.05$ for differences between the WAY100635+DcM and control-, DcMor WAY100635-treated groups. ${ }^{*} P<0.05$ for difference between the (-)-pindolol+DcM and DcM-treated group

WAY $_{100635}$ with DcM $(4.0 \mathrm{mg} / \mathrm{kg})$ as compared to the control, DcM- or WAY ${ }_{100635}$-treated groups.

Table 4 shows the response of the number of crossings in the OFT to treatment with saline or $(+)-8-0 H-D P A T ~(0.20$ or $0.33 \mu \mathrm{g})$ in rats chronically treated with vehicle or DcM (5.0 $\mathrm{mg} / \mathrm{kg}$ ) in the OFT. The two-way ANOVA shows an effect of $(+)-$ 8-OH-DPAT treatment $\left(\mathrm{F}_{(2.52)}=4.9, \mathrm{P}=0.01\right)$, but not of DcM treatment $\left(\mathrm{F}_{(1,52)}=0.03, \mathrm{P}=0.87\right)$ or of $(+)-8-0 H-D P A T ~ X ~ D c M$ interaction $\left(\mathrm{F}_{(2.52)}=2.6, \mathrm{P}=0.09\right)$ on the number of crossings. Post hoc Tukey 's comparisons indicated significant differences $(\mathrm{P}<0.05)$ between the $(+)-8-0 H-D P A T(0.20 \mu \mathrm{g})$-treated group and (+)-8-OH-DPAT $(0.30 \mu \mathrm{g})$-treated group, showing a (+)-8OH-DPAT effect on the number of crossings in the OFT.

Table 5 shows the effect of treatment of (-)-pindolol $(0.10$ $\mu \mathrm{g})$ or $\mathrm{WAY}_{100635}(0.43 \mu \mathrm{g})$ on the number of crossings in rats chronically treated with a subactive dose of DcM $(4.0 \mathrm{mg} / \mathrm{kg})$ and subjected to the OFT. The two-way ANOVA shows no significant effect of (-)-pindolol $\left(\mathrm{F}_{(1.30)}=2.3, \mathrm{P}=0.14\right)$, of DcM treatment $\left(\mathrm{F}_{(1.30)}=0.004, \mathrm{P}=0.95\right)$ or of the association of $(-)$-pindolol $\mathrm{X}$ $\operatorname{DcM}\left(\mathrm{F}_{(1.30)}=0.17, \mathrm{P}=0.68\right)$. The two-way ANOVA indicated no effect of $\mathrm{WAY}_{100635}\left(\mathrm{~F}_{(1.30)}=3,0, \mathrm{P}=0,09\right)$, of DcM $\left(\mathrm{F}_{(1.30)}=\right.$ $0.04, \mathrm{P}=0.85)$ or of the association of $\mathrm{WAY}_{100635} \mathrm{X} \operatorname{DcM}\left(\mathrm{F}_{(1.30)}\right.$ $=0.02, \mathrm{P}=0.89)$.

\section{Discussion}

This study demonstrates that the DcM semipurified fraction from K. coriacea extract stems was active in the FST model of

\section{Table 4}

Effects of a combination of the DcM fraction with intraDRN microinjection of (+) 8-OH-DPAT on the number of crossings in the OFT

\begin{tabular}{|c|c|c|}
\hline \multirow[t]{2}{*}{ 5-HT $T_{1 A}$ agonist } & \multicolumn{2}{|c|}{$D c M(m g / k g)$} \\
\hline & $0 \mathrm{mg} / \mathrm{kg}$ & $5.0 \mathrm{mg} / \mathrm{kg}$ \\
\hline \multicolumn{3}{|c|}{$(+)-8-O H-D P A T(\mu g)$} \\
\hline 0 & $118.1 \pm 5.4$ & $131.3 \pm 14.9$ \\
\hline 0.20 & $124.6 \pm 12.9$ & $88.3 \pm 13.2$ \\
\hline 0.33 & $72.8 \pm 10.7^{\#}$ & $90.5 \pm 11.9$ \\
\hline
\end{tabular}

Data are means \pm SE, $(n=8-12)$ after intraDRN saline or $(+) 8-O H-D P A T(0.20$ or $0.33 \mu \mathrm{g})$ in rats treated with vehicle or DcM $(5.0 \mathrm{mg} / \mathrm{kg})$. ${ }^{*} P<0.05$ for difference between the $(+) 8$-OH-DPAT $(0.20 \mu \mathrm{g})$ and 8 -OH-DPAT $(0.33 \mu \mathrm{g})$-treated groups depression in rats. This result confirms previous dose-response curves obtained in our laboratory. These dose-response curves established the lowest active dose for chronic treatment effects and determined whether chronic administration was effective at doses that were ineffective after acute or subacute treatment with the DcM fraction from K. coriacea. ${ }^{[3]}$ Thus, the DcM fraction was active in the FST when administered for 45 days at a dose of $5.0 \mathrm{mg} / \mathrm{kg}$ but not at a dose of $4.0 \mathrm{mg} / \mathrm{kg}$. This antiimmobility effect of the DcM fraction does not reflect a general increase in motor activity because the same dose which induced an antidepressant-like effect did not increase locomotion in the OFT. The antiimmobility effect detected after chronic but not after acute or subacute treatment of DcM in the FST is consistent with other findings. ${ }^{[18]}$

Acute administration of selective 5-HT (serotonin) re-uptake inhibitors (SSRIs) and other antidepressant drugs induces an increase in the concentration of 5-HT in the vicinity of 5-HT cell bodies in midbrain raphe nuclei. It also triggers activation of $5-\mathrm{HT}_{1 \mathrm{~A}}$ somatodendritic autoreceptors, thus inhibiting the firing activity of the 5-HT neurons and reducing the release of 5-HT in the forebrain. ${ }^{[6-8]}$ Studies have shown that intraraphe or systemic administration of 5- $\mathrm{HT}_{1 \mathrm{~A}}$ antagonists, $\mathrm{WAY}_{100635}$ or pindolol, markedly potentiates the activity of SSRIs. This potentiation is due to the blockade of activation of $5-\mathrm{HT}_{1 \mathrm{~A}}$ receptors by SSRIs, reducing negative feedback and resulting in increased 5-HT neuronal cell firing as well as inducing an increase of extracellular 5 -HT levels in forebrain areas. ${ }^{[19-21]}$ The combined administration of SSRI and pindolol has been found to accelerate the onset of antidepressant treatment in preclinical and clinical studies and / or to improve antidepressant therapy in resistant patients. ${ }^{[9,10]}$

In the present study, significant potentiation of the antiimmobility effect of a subactive dose of the DcM fraction by pretreatment with the $5-\mathrm{HT}_{1 \mathrm{~A} / 1 \mathrm{~B} /}$ Badrenergic antagonist (-)-pindolol or with the 5-HT ${ }_{1 \mathrm{~A}}$ antagonist $\mathrm{WAY}_{100635}$ in the FST clearly highlights the involvement of $5-\mathrm{HT}_{1 \mathrm{~A}}$ receptors in the antidepressant-like effect of the DcM fraction of $\mathrm{K}$. coriacea. Pindolol is also known to block $\beta$-adrenoceptors but considering the reports of increased incidence of depressive disorders due to B-adrenergic blockers, it is unlikely that $B$-adrenoceptor inhibition enhances the efficacy of antidepressant drugs. ${ }^{\text {[2] }}$ Studies show that agents capable of blocking $5-\mathrm{HT}_{1 \mathrm{~A}}$ autoreceptors including the mixed $5-\mathrm{HT}_{1 \mathrm{~A} / 1 \mathrm{~B} /} \mathrm{B}$-adrenergic receptor blockers and SSRIs, produce an enhanced antidepressant effect whereas

\section{Table 5}

Effects of a combination of subactive dose of DcM fraction with intraDRN microinjection of (-)-pindolol or WAY ${ }_{100635}$ on the number of crossings in the OFT

\begin{tabular}{|c|c|c|}
\hline \multirow[t]{2}{*}{ 5-HT $T_{1 A}$ antagonist } & \multicolumn{2}{|c|}{$D c M(m g / k g)$} \\
\hline & $0 \mathrm{mg} / \mathrm{kg}$ & $4.0 \mathrm{mg} / \mathrm{kg}$ \\
\hline - & $118.1 \pm 5.4$ & $122.6 \pm 14.7$ \\
\hline WAY $_{100635}(0.43 \mu \mathrm{g})$ & $96.4 \pm 15.6$ & $97.2 \pm 11.7$ \\
\hline (-)-pindolol $(0.10 \mu \mathrm{g})$ & $109.3 \pm 12.4$ & $104.6 \pm 9.0$ \\
\hline
\end{tabular}


B-adrenoceptor antagonists lacking 5 - $\mathrm{HT}_{1 \mathrm{~A}}$ receptor affinity do not enhance the antidepressant effect of SSRIs. ${ }^{[23]}$ Despite differences in specificity between (-)-pindolol and $\mathrm{WAY}_{100635}$ for $5-\mathrm{HT}_{1 \mathrm{~A}}$ receptors, the facilitation of an antidepressant-like effect of DcM by both compounds is probably due to the antagonist activity of the DcM fraction on 5-HT ${ }_{1 \mathrm{~A}}$ receptors.

Our results are consistent with other reports ${ }^{[9,10]}$ where (-)-pindolol or $\mathrm{WAY}_{100635}$ produced no alterations in immobility times in the FST or in the number of crossings in the OFT. Thus, our data showed that both (-)-pindolol and $\mathrm{WAY}_{100635}$ exerted antagonist-like properties on $5-\mathrm{HT}_{1 \mathrm{~A}}$ receptors. Alone they produced no effect but when combined with a subactive dose of DcM, they facilitated its antidepressant-like effect in the FST through inhibition of $5-\mathrm{HT}_{1 \mathrm{~A}}$ somatodendritic autoreceptors in the DRN and enhanced release of 5-HT.

In our study, an intraDRN microinjection of (+)-8-OH-DPAT $(0.33 \mu \mathrm{g})$ increased immobility time in the FST and reduced locomotion in the OFT. Both effects could be related to a reduced serotonergic function mediated by the activation of $5-\mathrm{HT}_{1 \mathrm{~A}}$ somatodendritic autoreceptors in the DRN. An intraDRN microinjection of (+)-8-OH-DPAT inhibits neuronal firing and reduces the release of 5 -HT in innervated structures in the forebrain. ${ }^{[13]}$ Behavioral studies demonstrate that activation of $5-\mathrm{HT}_{1 \mathrm{~A}}$ receptors by intraDRN $5-\mathrm{HT}_{1 \mathrm{~A}}$ agonists triggers the inhibition of motility whereas $5-\mathrm{HT}_{1 \mathrm{~A}}$ antagonists have the opposite effect. This suggests that both effects are mediated by $5-\mathrm{HT}_{1 \mathrm{~A}}$ receptors located in the $\mathrm{DRN}$. $^{24]}$

The involvement of $5-\mathrm{HT}_{1 \mathrm{~A}}$ receptors in the antidepressantlike effect of the DcM fraction of K. coriacea, as well as in the increase in the immobility time produced by the $(+)$ 8-OH-DPAT is confirmed by the annulation of the effects produced in the FST by each one in the combined treatment. However, the influence of $5-\mathrm{HT}_{1 \mathrm{~A}}$ agonists on the release of several neurotransmitters in the limbic regions of the brain has been shown in different studies and may be an alternative explanation for the results observed in our study..$^{[8]}$

Despite the possible involvement of different neurotransmitters / receptors in the antidepressant-like effect of the combination of the active dose of the DcM fraction and (+)-8-OH-DPAT in the FST, (+)-8-OH-DPAT, the synergism observed with the subactive dose of the DcM fraction and (-)-pindolol or $\mathrm{WAY}_{10063}$, suggests the involvement of $5-\mathrm{HT}_{1 \mathrm{~A}}$ receptors. In conclusion, the DcM semipurified fraction of $\mathrm{K}$. coriacea stem extract interacts with 5-HT ligands and produces an antidepressant-like effect in the FST. Thus, the active principle(s) in the DcM semipurified fraction show promise for their use in the treatment of mood disorders such as depression.

\section{Acknowledgements}

The authors thank Marcos Alberto Trombelli for technical assistance. This study was supported by the Fundação Araucária, Brazil.

\section{References}

1. Alves TM, Silva AF, Brandão M, Grandi TS, Smânia EF, Smânia Junior A, et al. Biological screening of Brazilian medicinal plants. Mem Inst Osvaldo Cruz 2000;95:367-73

2. Cortez DA, Young MC, Marston A, Wolfender L, Hostettmann K. Xanthones, Triter- penes and a Biphenyl from Kielmeyera coriacea. Phytochemistry 1997;46:1367-74.

3. Martins JV, Otobone FJ, Sela VR, Obici S, Trombelli MA, Garcia DA, et al. Evaluation of semi-pure fraction of extract from Kielmeyera coriacea stems, through behavioral tests in rats. Indian J Pharmacol 2006;38:427-8.

4. Martins JV, Otobone F, Sela VR, Obici S, Trombelli MA, Cortez DA, et al. Activity of hydroethanolic extract from Kielmeyera coriacea stems on central nervous system in rats. Acta Sci Health Sci 2004;26:365-8.

5. Hjorth S, Bengtsson HJ, Kullberg A, Carlzon D, Peilot H, Auerbach SB. Serotonin autoreceptor function and antidepressant drug action. J Psychopharmacol 2000;14:177-85.

6. Pineyro G, Blier P. Autoregulation of serotonin neurons: Role in antidepressant drug action. Pharmacol Rev 1999;51:533-91.

7. Hoyer D, Hannon JP, Martin GR. Molecular, pharmacological and functional diversity of 5-HT receptors. Pharmacol Biochem Behav 2002;71:533-54.

8. Lechin F, van der Dijs B, Hernández-Adrian G. Dorsal raphe vs. median raphe serotonergic antagonism. Anatomical, physiological, behavioral, neuroendocrinological, neuropharmacological and clinical evidences: relevance for neuropharmacological therapy. Prog Neuropsyghopharmacol Biol Psychiatry 2006;30:565-85.

9. Tatarczynska E, Klodzinska A, Chojnacka-WojcikE. Effects of combined administration of 5- $\mathrm{HT}_{1 \mathrm{~A}}$ and/or $5-\mathrm{HT}_{1 \mathrm{~B}}$ receptor antagonists and paroxetine or fluoxetine in the forced swimming test in rats. Pol J Pharmacol 2002;54:615-23.

10. Artigas F, Romero L, de Montigny C, Blier P. Acceleration of the effect of selected antidepressant drugs in major depression by $5-\mathrm{HT}_{1 \mathrm{~A}}$ antagonists. Trends Neurosc 1996;19:378-83.

11. Porsolt RD, Anton GD, Jalfre M. Behavioural despair in rats: Anew model sensitive to antidepressant treatments. Eur J Pharmacol 1978;47:379-91.

12. Paxinos $G$, Watson $C$. The rat brain in stereotaxic coordinates. $4^{\text {th }}$ ed. Academic Press Inc: San Diego; 1998.

13. Romaniuk A, Koprowska M, Krotewicz M, Strzelczuk M, Wieczorek M. Effects of 8-OHDPAT administration into the dorsal raphe nucleus and dorsal hippocampus on fear behavior and regional brain monoamines distribution in rats. Behav Brain Res 2001;120:47-57.

14. Assié MB, Koek W. Estimation of apparant pA2 values for $\mathrm{WAY}_{100635}$ at $5-\mathrm{HT}_{1 \mathrm{~A}}$ receptors regulating 5 -hyudroxytryptamine release in anaesthetised rats. Eur $J$ Pharmacol 2000;409:173-7.

15. Assié MB, Koek W. Effects of 5-HT hydroxytryptamine levels: (S)-WAY ${ }_{100135}$, but not WAY ${ }_{100635}$, has partial agonist properties. Eur J Pharmacol 1996;304:15-21.

16. Assié MB, Koek W. (-)-pindolol and ( \pm ) tertatolol affect rat hippocampal 5-HT levels through mechanisms involving not only $5-\mathrm{HT}_{1 \mathrm{~A}}$, but also $5-\mathrm{HT}_{1 \mathrm{~B}}$ receptors. Neuropharmacol 1996;2:213-22.

17. Detke MJ, Lucki I. Detection of serotonergic and noradrenergic antidepressants in the rat forced swimming test: The effects of water depth. Behav Brain Res 1996;73:43-6.

18. Detke MJ, Johnson J, Lucki I. Acute and chronic antidepressant drug treatment in the rat forced swimming test model of depression. Exp Clin Psychopharmacol 1997:5:107-12.

19. Romero L, Hérvas I, Artigas F. The $5-\mathrm{HT}_{1 \mathrm{~A}}$ antagonist $\mathrm{WAY}{ }_{100635}$ selectively potentiates the presynaptic effects of serotonergic antidepressants in rat brain. Neurosc Let 1996;219:123-6.

20. Gartside SE, Umbers V, Hajós M, Sharp T. Interaction between a selective $5-\mathrm{HT}_{1 \mathrm{~A}}$ receptor antagonist and SSRI in vivo: Effects on 5-HT cell firing and extracellular 5-HT. Br J Pharmacol 1995;115:1064-70.

21. Romero L, Bel N, Artigas F, Montigny C, Blier P. Effect of pindolol on the function of pré- and postsynaptic 5- $\mathrm{HT}_{1 \mathrm{~A}}$ receptors: In vivo microdialysis and elctrophysiological studies in the rat brain. Neuropsychopharmacol 1996;15:349-60.

22. Avorn J, Everitt DE, Weiss S. Increased antidepressant use in patients prescribed beta-blockers. JAMA 1986;255:357-60.

23. Hjorth $\mathrm{S}$, Bengtsson $\mathrm{HJ}$, Milano $\mathrm{S}$. Raphe $5-\mathrm{HT}_{1 \mathrm{~A}}$ autoreceptors, but not postsynaptic $5-\mathrm{HT}_{1 \mathrm{~A}}$ receptors or $\beta$ adrenoreceptors, restrain the citalopraminduced increase in extracellular 5 -hydroxytryptamine in vivo. Eur $\mathrm{J}$ Pharmacol 1996;316:43-47.

24. Karakamus PN, Pappas P, Marselos M. Involvement of the brain serotonergic system in the locomotor stimulant effects of chlorpheniramine in Wistar rats: Implication of postsynaptic 5- $\mathrm{HT}_{1 \mathrm{~A}}$ receptors. Behav Brain Res 2004;148:199208. 